\title{
Recent patents in pharmacogenomics
}

\begin{tabular}{|c|c|c|c|c|c|}
\hline Patent \# & Subject & Assignee & Inventor(s) & $\begin{array}{c}\text { Priority } \\
\text { application } \\
\text { date }\end{array}$ & $\begin{array}{l}\text { Publication } \\
\text { date }\end{array}$ \\
\hline US 6376225 & $\begin{array}{l}\text { A nucleic acid encoding a human phosphodiesterase (PDE) } \\
\text { that is an alternative splice form of PDE2A; useful as a mode } \\
\text { or target for the identification and development of therapeutic } \\
\text { agents, for recombinant expression of PDE, for monitoring } \\
\text { the effect of modulators, and in pharmacogenomics. }\end{array}$ & $\begin{array}{l}\text { PE Corp. } \\
\text { (Norwalk, CT) }\end{array}$ & $\begin{array}{l}\text { Beasley EM } \\
\text { Di Francesco V, } \\
\text { Merkulov GV } \\
\text { Wang X, } \\
\text { Wei M }\end{array}$ & $1 / 5 / 2001$ & 4/23/2002 \\
\hline WO 200230562 & $\begin{array}{l}\text { An integrated biochip system that uses active and multi-force } \\
\text { chips to carry out several sequential processing tasks such } \\
\text { as separation, purification, and isolation; useful for biomed- } \\
\text { ical applications such as medical diagnosis, genetic testing, } \\
\text { prognostics, and pharmacogenomics. }\end{array}$ & $\begin{array}{l}\text { AVIVA } \\
\text { Biosciences } \\
\text { (San Diego, } \\
\text { CA) }\end{array}$ & $\begin{array}{l}\text { Cheng J, } \\
\text { Wang X, } \\
\text { Wu L, } \\
\text { Xu J, } \\
\text { Yang W }\end{array}$ & $10 / 10 / 2000$ & 4/18/2002 \\
\hline WO 200226984 & $\begin{array}{l}\text { An isolated potassium-channel interactor polypeptide useful } \\
\text { for treating central nervous-system disorders, epilepsy, spino- } \\
\text { cerebellar ataxia, cardiovascular disorders, and in screening } \\
\text { assays, detection assays (chromosomal mapping, tissue } \\
\text { typing, and forensic biology), and predictive medicine (diag- } \\
\text { nostic assays, prognostic assays, clinical-trial monitoring, } \\
\text { and pharmacogenomics). }\end{array}$ & $\begin{array}{l}\text { Millennium } \\
\text { Pharma- } \\
\text { ceuticals } \\
\text { (Cambridge, } \\
\text { MA) }\end{array}$ & $\begin{array}{l}\text { An W, } \\
\text { Betty M, } \\
\text { Ling H, } \\
\text { Rhodes K }\end{array}$ & $10 / 31 / 2000$ & 4/4/2002 \\
\hline WO 200224894 & $\begin{array}{l}\text { A substantially isolated human protease-inhibitor protein } \\
\text { (HPI), } 86 \text { amino acids long, that shares structural similarity } \\
\text { with animal protease inhibitors and other animal proteins } \\
\text { including serine protease inhibitors, follistatin, and ovomucoid } \\
\text { inhibitors; useful for generating antibodies, as reagents in } \\
\text { diagnostic assays, and in pharmacogenomics. }\end{array}$ & $\begin{array}{l}\text { Lexicon } \\
\text { Genetics } \\
\text { (The Wood- } \\
\text { lands, TX) }\end{array}$ & $\begin{array}{l}\text { Donoho G, } \\
\text { Friddle CJ, } \\
\text { Hilbun E }\end{array}$ & $9 / 21 / 2000$ & 3/28/2002 \\
\hline WO 200225528 & $\begin{array}{l}\text { A system for use in delivering decision-supported patient } \\
\text { data to a clinician, comprising a knowledge module, a } \\
\text { patient module, an inference module, and a user module. } \\
\text { The system effectively gathers patient data without a lengthy } \\
\text { examination of the patient and evaluates the data to identify } \\
\text { known or unknown medical conditions. }\end{array}$ & $\begin{array}{l}\text { TheraDoc.com } \\
\text { (Salt Lake } \\
\text { City, UT) }\end{array}$ & $\begin{array}{l}\text { Baza ME, } \\
\text { Boekweg RJ, } \\
\text { Eardley DD, } \\
\text { Evans SR, Harty } \\
\text { Lu B, Olson JB, } \\
\text { Pestotnik SL, Rub } \\
\text { Samore MH, Sanc } \\
\text { Skolnick MH, Stult } \\
\text { Tettelbach WH }\end{array}$ & $\begin{array}{l}\text { 9/21/2000 } \\
\text { VF } \\
\text { in MA, } \\
\text { le MA, } \\
\text { s BM, }\end{array}$ & 3/28/2002 \\
\hline WO 200222826 & $\begin{array}{l}\text { A library of nucleic acid-protein (NAP) conjugates compris- } \\
\text { ing a fusion polypeptide with a nucleic-acid modification } \\
\text { (NAM) enzyme and a candidate compound, and an express- } \\
\text { ion vector with a fusion of nucleic acids encoding the NAM } \\
\text { enzyme and the candidate protein; useful for detecting the } \\
\text { presence of a target analyte in a sample, in screens, and in } \\
\text { pharmacogenomic studies. }\end{array}$ & $\begin{array}{l}\text { Xencor } \\
\text { (Monrovia, } \\
\text { CA) }\end{array}$ & $\begin{array}{l}\text { Li M, } \\
\text { Liu H, } \\
\text { Melander C }\end{array}$ & $9 / 14 / 2000$ & 3/21/2002 \\
\hline WO 200220764 & $\begin{array}{l}\text { An isolated human transporter peptide whose sequence is } \\
\text { selected from a fully defined sequence of } 931 \text { amino acids; } \\
\text { useful in identifying modulators of transporter peptides, in } \\
\text { pharmacogenomic analysis, or as a target for diagnosing a } \\
\text { disease or predisposition to a disease mediated by the peptide. }\end{array}$ & $\begin{array}{l}\text { PE Corp. } \\
\text { (Norwalk, } \\
\text { CT) }\end{array}$ & $\begin{array}{l}\text { Beasley E, } \\
\text { Bonazzi V, } \\
\text { Chandramouliswe } \\
\text { Gan W } \\
\text { Yan C }\end{array}$ & $\begin{array}{l}\text { 9/11/2001 } \\
\text { an I, }\end{array}$ & $3 / 14 / 2002$ \\
\hline WO 200220832 & $\begin{array}{l}\text { A method for determining the presence or absence of a } \\
\text { target nucleic acid in a sample by forming a hybridization } \\
\text { complex of target and probe that is on the surface of a } \\
\text { piezoelectric biosensor, and measuring a parameter of the } \\
\text { biosensor to detect the target; useful in tumor diagnostics, } \\
\text { transplantation analyses, genome diagnostics, pharmaco- } \\
\text { genomics, and gene expression analysis. }\end{array}$ & $\begin{array}{l}\text { Atonomics } \\
\text { (Copenhagen, } \\
\text { Denmark) }\end{array}$ & Warthoe P & $1 / 12 / 2001$ & $3 / 14 / 2002$ \\
\hline EP 1158058 & $\begin{array}{l}\text { A method of nucleic acid (NA) analysis that initiates contact of } \\
\text { at least two NA samples having different radiolabels with an } \\
\text { array of NAs, then detects the hybrids formed; used to detect } \\
\text { and quantify a target NA for diagnosis, to monitor gene exp- } \\
\text { ression and compare expression patterns between different } \\
\text { cell types, and in pharmacogenomics applications. }\end{array}$ & $\begin{array}{l}\text { Centre } \\
\text { National de } \\
\text { la Recherche } \\
\text { Scientifique } \\
\text { (France) }\end{array}$ & $\begin{array}{l}\text { Dumas S, } \\
\text { Mallet J, } \\
\text { Vujasinovic T }\end{array}$ & $5 / 19 / 2000$ & $11 / 28 / 2001$ \\
\hline
\end{tabular}

Source: Derwent Information, Alexandria, VA. The status of each application is slightly different from country to country. For further details, contact Derwent Information, 1725 Duke Street, Suite 250, Alexandria, VA 22314. Tel: 1 (800) DERWENT (info@derwent.com). 